\title{
1. The world society context: the globalisation of labour law
}

An assessment of modern labour law that does not take the impact of global processes seriously can nowadays no longer claim to have an adequate understanding of the field. The thesis developed in this chapter will be that the sociological theory of the world society espoused by Niklas Luhmann and the accompanying theory of global law, of which Gunther Teubner is a leading protagonist, provide useful concepts for the interpretation of developments in modern labour law.

The chapter consists of five sections. The first section provides a brief overview of the development of Luhmann's thinking about law and politics as social systems, followed in the second section by an outline of his theory of world society. The third section contains observations on specific problems of law and politics in the world society. The fourth section is devoted to an introduction of Luhmann's concept of world law and Gunther Teubner's ideas on global law, and finally, building on Luhmann's and Teubner's concepts, the fifth section gives a first assessment of globalisation of labour law.

\subsection{THE THEORETICAL BACKGROUND: NIKLAS LUHMANN'S THEORY OF LAW AND POLITICS AS SOCIAL SYSTEMS}

Modern society is, according to Niklas Luhmann, a system of communication. It is characterised by a specific mode of integration called functional differentiation which implies that modern society is no longer hierarchically ordered but differentiated into a number of function systems. Functional differentiation has replaced segmentation and stratification as the dominant modes of integration and as a consequence modern society has become plural in nature. It has no centre that controls its development as a whole or is capable of directing its function systems. Each function system in modern society follows its own trajectory.

Law and politics are two main societal function systems and they have been prominent in Luhmann's sociological approach. Since the beginning 
of developing his theory of modern society in the 1960s, Luhmann conceived law and politics as social systems that fulfil specific functions in modern society and engage in performances for each other and other function systems. However, Luhmann analysed different aspects of law and politics in his early work, his writings of the middle period and his late work. ${ }^{1}$

The majority of Luhmann's early writings of the 1960s and 1970s dealt with aspects of law and administration and borrowed from his work experiences as a trained jurist and civil servant. Probably the most ambitious theoretical account of law in this period was put forward in his Rechtssoziologie (Sociology of Law) (Luhmann 1972). ${ }^{2}$ The traditional behaviourist approach of sociolegal studies was replaced in this work with a surprising new starting point in studying law in society. This new view took a fresh look at how law emerges in society by claiming that stabilisation of expectations in society is the main function of law. The autonomy of the function system of law is viewed as the result of a cunning combination of cognitive and normative attitudes in dealing with disappointments of expectations. This approach represents a brilliant attempt in analysing the emergence and development of law and the creation of a legal system by using concepts borrowed from cybernetics and evolution theory.

In accordance with modern legal theory and classical sociology of law, in particular Max Weber, Emile Durkheim and Eugen Ehrlich, the main focus is on explaining conditions that make positive law possible. However, Luhmann switches the focus from themes central in debates on legal positivism, i.e. validity or legitimation of law in society, to an analysis of norms, institutions and legal doctrine as mechanisms that enable law to control its own development by upholding normative expectations. The crucial aspect in Luhmann's sociological account of positive law is that law now has the means to change itself. Furthermore, modern law is capable of dealing with and adopting cognitive expectations. Normative structures can no longer claim to have eternal value. Modern legal norms are adaptable and can always be changed, although not on the spot and only through the use of procedures. The fundamental character of modern positive law is that it is contingent and open towards the future.

Luhmann refined his system theory approach in the second phase which was marked by the adoption of the theory of autopoiesis in conceptualising

1 Distinguishing stages in Luhmann's analyses of law and politics does not imply that the different concepts of law and politics that are dominant in each period contradict each other. In fact, they complement each other.

2 The English title of this book, A Sociological Theory of Law (Luhmann 1985a), captures its content more accurately. 
social systems (Luhmann 1995a; first published in German in 1984). This phase culminated, insofar as law is concerned, in the publication of Recht der Gesellschaft (Luhmann 1993, translated into English as Law as a Social System in 2005) and in relation to politics in the posthumous Politik der Gesellschaft (Luhmann 2000a). Law and politics are no longer conceived as just autonomous but as autopoietic in nature. Law and politics are systems of communication that are operationally closed and reproduce themselves. Specific political and legal communications, and not political or legal actions or institutions, enable these function systems to engage in sophisticated processes of self-reproduction.

By adopting the concept of autopoiesis, Luhmann radicalised the notion of autonomy of social systems. Systems are not only capable of reproducing themselves, but any perception of society and the world at large becomes system-specific and happens inside a social system. This radical internalisation in sociological thinking and the almost exclusive focus on self-reference of systems led to the critique of Jürgen Habermas that Luhmann endows social system with attributes characteristic of the subject in the tradition of idealist philosophy (Habermas 1987, pp. 368-85).

The last phase in Luhmann's work was devoted to an elaboration of the fundamental characteristics of modern society. The book Gesellschaft der Gesellschaft (Luhmann 1997a), written a year before Luhmann's death, is in many respects the opus magnum of this phase. Law and politics are consistently analysed from the perspective of a functionally differentiated world society. In his last phase Luhmann became particularly interested in the emergence of global structures and the problems that function systems create for each other in the world society. The economy, science and technology are viewed as fully globalised due to their cognitive orientations. Other function systems such as law and politics, although also globalising, lag behind because they still operate to a large degree with territorial boundaries (see Stichweh 1995, 2000a, 2000b, and on world law see in particular Lieckweg 2003, and also Rogowski 2000b and Schulte and Stichweh 2009).

\subsection{THEORY OF THE WORLD SOCIETY}

The concept of the world society that dominates Luhmann's late work was already conceptually developed in his early work. In the article Die Weltgesellschaft, published in 1971 (Luhmann 1975 [1971]), the emergence of the world society is described as a necessary consequence of functional differentiation. Function systems that have a high degree of autonomy 
'detonate' societal boundaries. Most advanced in this respect are the economy, technology and science. In particular science is said to have adopted universal intersubjectivity as its own structuring principle and criterion of performance. In contrast law and politics remain backward in this respect by clinging on to territorial boundaries.

In his 1982 article 'The World Society as a Social System' (Luhmann 1990a [1982]) Luhmann outlines how the main features of his theory of society can be used for a study of society at the world level. The concept of the world society 'provides one world for one system; and it integrates all world horizons as horizons of one communicative system' (Luhmann 1990a [1982], p. 178). Luhmann adopts the radical solution of not distinguishing between the society and world society. On a number of occasions he stated in this period of his writings that 'there exists today only one society on earth: the world society' (Luhmann 1976, p. 526) and that it therefore does not make sense to talk about national societies in the plural.

What is remarkable is the overlap of the main sections of the World Society article with the chapters of his final book on the theory of society, Gesellschaft der Gesellschaft, published 15 years later in 1997 (English translation of Vol. 1 in Luhmann 2012). In the 1982 article we already find a brief general outline of how system theoretical features can be used to conceptualise world society, including remarks on evolution, differentiation and self-description of society. This theoretical design reveals resilience in Luhmann's unique approach in developing a sociology of modern society, including the world society. Luhmann is realistic in that system theory is unlikely to contribute much in solving society's problems but, as he states at the end of the World Society article, it promises at least 'arriving at a higher level of intelligibility' (Luhmann 1990a [1982], p. 187).

An important reason for the globalisation of function systems rests in the fact that at the operational level they consist of self-reproducing communications. Since it is difficult to prevent communications from flowing across territorial boundaries, it makes it almost impossible to isolate function systems from world processes. All function systems are exposed to the pressure of globalisation that results from worldwide communications.

Luhmann's theory of the world society is neither a new theory of international relations nor a new version of globalisation theory. It is a theory about the structures of society at world level that possess genuine properties. It thus does not predict a diminishing of territorial borders; it only emphasises the increasing necessity to redefine national borders as a result of the evolving world society (see Stichweh 1995, 2000a, 2000b, 2005). There are remarkable differences between Luhmann and Parsons in defining world society. The 'international system' was genuinely political for Parsons and nation states and territorial boundaries mattered. For 
Luhmann world society consists of only one global system in which at least conceptually countries do not matter (Stichweh 2005).

In his posthumously published political sociology Luhmann analysed the paradoxical impact of globalisation on national political and legal systems. National law and politics are at the same time weakened and strengthened. The conditions of the new political order require that a minimum degree of statehood is guaranteed. States become recognised as full members by the international community if they fulfil international legal criteria of statehood (Albert 2005). It is this external recognition that constitutes the core of sovereignty of states in the world society.

Regions cannot participate in politics without adopting the form of a 'sov-
ereign' state (and there are no regions that can avoid this). That this does
no longer guarantee stability becomes increasingly the main problem in the
new international order (as it is called optimistically). However, a state must
be more than simply an address for international communications. Political
effectiveness and internal authority are indispensable conditions. It cannot be
excluded that the system of world politics will increasingly be driven to act as
guarantor of statehood without intermingling in regional politics. However,
suitable forms of intervention that match this task do not yet exist and will have
to be developed (Luhmann $2000 \mathrm{a}, \mathrm{pp}$. 225-6, translation R.R.).

In his article 'Globalization or World Society: How to Conceive of Modern Society?' (Luhmann 1997b), Luhmann went a step further. The world society does not only impose new conditions on politics and law but is itself the cause for manifold regional, economic, cultural, climatic and ecological differences. In the case of the global political system he demonstrated that the global demand for a functioning 'political state' can lead to new nationalisms and even more importantly that the lack of recognition, assistance and powers of intervention at the global level can constitute 'global neglect', which stimulates negative reactions at national level.

... a sociological theory that wants to explain these differences, should not introduce them as givens, that is, as independent variables; it should rather start with the assumption of a world society and then investigate, how and why this society tends to maintain or even increase regional inequalities. It is not very helpful to say that the Serbs are Serbs and, therefore, they make war. The relevant question is rather, whether or not the form of the political state forced upon all regions on earth fits to all local and ethnic conditions, or, whether or not the general condition, not of exploitation or suppression but of global neglect stimulates the search for personal and social, ethnic or religious identities (Luhmann 1997b, p. 73).

Luhmann criticises standard sociological accounts of globalisation and contemporary moral and philosophical theories of distributive justice of 
misunderstanding the real reasons for the new miseries at the world level. The real reasons are related in Luhmann's account to the fundamental shift from stratification to functional differentiation in modern society and concepts such as 'exploitation' and 'suppression', prominent in international relations theory, overlook for him the fact that the world society has no hierarchical order.

If we look at the huge masses of starving people, deprived of all necessities for a decent human life, without access to any of the function systems, or if we consider all the human bodies, struggling to survive the next day, neither 'exploitation' nor 'suppression' - terms that refer again to stratification - are adequate descriptions. It is only by habit and by ideological distortion that we use these terms. But there is nothing to exploit in the favelas; nor are there, at the higher levels of society, actors or dominant groups that use their power to suppress these people. (There are of course individuals, families or groups which, like everyone else, use their networks to their own advantage.) 'Exploitation' and 'suppression' are outdated mythologies, negative utopias suggesting an easy way out of this situation, e.g. by 'revolution'. The predominant relation is no longer a hierarchical one, but one of inclusion and exclusion; and this relates not to stratification but to functional differentiation (Luhmann 1997b, p. 70).

The problem of exclusion is likely to reach dangerous proportions in the world society according to Luhmann. In fact he went so far as to predict that inclusion and exclusion will become the new metacode in the world society. In describing the consequences of exclusion he paints a real dystopia that comes close to the analysis of bare life in Giorgio Agamben's Homo Sacer (Agamben 1998):

The worst imaginable scenario might be that the society of the next century will have to accept the metacode of inclusion/exclusion. And this would mean that some human beings will be persons and others only individuals; that some are included into function systems for (successful or unsuccessful) careers and others are excluded from these systems, remaining bodies that try to survive the next day; that some are emancipated as persons and others are emancipated as bodies; that concern and neglect become differentiated along this boundary; that tight coupling of exclusions and loose couplings of inclusions differentiate fate and fortune: and that two forms of integration will compete: the negative integration of exclusions and the positive integration of inclusions (Luhmann 1997b, p. 76).

Luhmann's world society concept overcomes many of the weaknesses of international relations theory. In the major strands of international relations theory, be it realist, liberal or constructivist approaches (Armstrong et al. 2012), the process of internationalisation is usually simply conceptualised as a gradual process of expanding international trade, of intensified interdependence of nation states or an increase in functions and powers 
of intergovernmental organisations. Such a view of internationalisation is criticised by the world society concept for insufficiently assessing the fundamental transformations that are happening in the process of internationalisation.

In sociological and political discussions an alternative paradigm that tries to grasp the new quality of these processes has emerged which is commonly referred to as the concept of globalisation. Theories of globalisation can be divided into approaches which reserve the concept of society to the nation state and those which opt for an encompassing concept of a world society (see also Anderson 2005). The first type is still the most common approach. In his account of the global system Leslie Sklair, for example, focuses on practices of transnational corporations (Sklair 1995, 2002). Anthony Giddens prefers a low-key approach to globalisation by simply mapping institutional dimensions centred on notions of increased time and space distanciation and of disembedding of social relations from local contexts (Giddens 1990, pp. 63-78). Malcolm Waters emphasises symbolic cultural exchanges, liberated from spatial referents, as key factors of globalisation (Waters 2000). Roland Robertson promotes the idea of the global field with culture as the core instance and institutionalisation of local particularisms as core processes of globalisation (Robertson 1992). And finally Martin Albrow puts forward a grandiose phenomenological account of fundamental historical transformations which give birth to a new epoch of mankind, called the global age (Albrow 1996). He criticises postmodern analyses, in particular the thesis of the end of meta-narratives (Lyotard 1984 [1979]) as end-of-epoch accounts which Albrow replaces with his beginning-of-epoch idea of the global age.

These accounts of globalisation processes are quite perceptive in describing the many forms in which the globe serves as focus for human activities (see the overview in Scholte 2005). However, they are unable to understand how the heterogeneous processes are used by the social system at world level in creating its own structure. Theories which study the global social system as such argue that non-synchronical levels of development should be understood as structural effects of the world social system. Three main approaches can be distinguished in this respect: John W. Meyers' concept of the world society, Immanuel Wallerstein's worldsystems theory and Niklas Luhmann's theory of the world society.

John W. Meyers' approach constitutes an ambitious attempt of a phenomenology of the world society based on rigid empirical studies of major function systems operating at the global level. His optimistic idea of a world society is particularly interested in alternative trajectories of 'world histories' and 'world futures'. Meyer's actor-centred institutionalist approach is overtly normative. His optimism rests on a belief in 
the transformative capacity of institutions and professions in creating the world society as a 'culturally imagined community' (Meyers 2010, p. 58).

The world-systems analysis of Immanuel Wallerstein is essentially an analysis of the history of capitalism. It assumes a 'single social system' at world level which consists of 'boundaries, structures, member groups, rules of legitimation and coherence' (Wallerstein 1974-1984, Vol. I, p. 347). These structures are analysed historically and statistically. There exist varieties of world-systems which include world-empires (political systems) and world-economies. Wallerstein analyses political blocks at the world level (the triadic scenario: US, Japan and Europe) and assumes that the world economy is following historical cycles (à la Kondratieff).

Aspects of labour and industrial relations are discussed under the rubric of 'world welfare' in Wallerstein's system. The world labour force is hierarchically structured. This structure is a prerequisite for the uneven distribution of wealth in the world-system. Labour is discussed as migrant labour, part-time female labour, wage impact on households, and rural labour (Tabak 1996; see also Shannon 1989, ch. 6 and 7). However, a reductionist economic bias hinders Wallerstein and his followers from adequately grasping the heterogeneous nature of global processes, including the independent and dynamic nature of law and industrial relations. The economic bias prevents this theory ultimately from becoming sociological and analysing the world system as world society. In defining society, Wallerstein adheres to an old-fashioned semantic concept of society as the entangled opposite of the state (see Wallerstein 1991, pp. 244-8).

There are few concepts that conceptualise the world society as a complex, encompassing system. An early concept was John Burton's World Society (Burton 1972). He proposed to study networks of social relations at the global level in which global 'systems' and 'states' interact. Since his intervention there has been a lively debate among international relations scholars, mainly refuting Burton's ideas as either too abstract or not going far enough. The dispute seems to have settled on a debate over an international versus a world society (Buzan 2004; on new systems theories of world society and world politics see Albert et al. 2010), whereby the concept of international society is clearly favoured by international relations scholars who feel more comfortable viewing the society at the global level as composed of and created by states (see Brown 2004 and the discussion in Bellamy 2004). Defenders of the world society concept among international relations theorists tend to emphasise the need to understand normative integration at the global level. They see the function of the world society concept in analysing the normative principles on which the international society rests (Clark 2007). Sociologists emphasise 
instead the inadequacy of applying the notion of national to the concept of society (Shaw 1994).

Luhmann's notion of the world society aims at a sociological analysis of modern society and is not intended to make a contribution to international relations theory. At best his theory can be used to observe this discipline (Albert and Hilkermeier 2004). However, in many respects his concept overcomes the weaknesses of world-systems theory and international relations theories by assuming functional differentiation of social systems at the world level. Luhmann's theory is an inclusive concept of world society which explains developments of the world society as a result of its internal operations (Stichweh 1995, p. 34).

Among Luhmann scholars, his theory of the world society has led to a lively discussion (see for example Albert et al. 2010). Helmuth Willke argues that it is still too early to speak of a world society. He only sees a few function systems that display true tendencies of globalisation. Globalisation has so far not led to a world society that is able to steer itself. He suggests that the global order should be called, somewhat artificially, a lateral world system (Willke 2001, in particular pp. 131-44). Willke's analysis focuses on the legal and political aspects of governance of the world society. This, however, is problematic because his analysis is ultimately based on the model of a society constituted by a nation state in which law and politics dominate the evolution of society as a whole.

Rudolf Stichweh emphasises that Luhmann himself has not carried out his programme of analysing all function systems consistently from the perspective of the world society, including law and politics (Stichweh 2002 , p. 289). This is also true of his final work on the theory of society, Gesellschaft der Gesellschaft (Luhmann 1997a, 2012). However, from the fact that Luhmann himself did not analyse extensively international organisations, respectively, globally active non-governmental organisations or global legal processes beyond traditional international law it cannot be concluded that he rejected the notions of world politics or world law. In fact, he has emphasised on numerous occasions that the world society possesses emergent properties and that this is true for world law and world politics as well.

Luhmann's theory of society is superior to most debates on globalisation because it not only avoids conceptual ambiguities but overcomes the helpless attitude when it comes to define the context in which globalisation happens. Methodologically it is a 'purely analytical' concept that rejects the notion of globalisation as a mere processualist narrative. In particular it refutes ethical claims and challenges views that associate world society with a global village or global polis (Schütz 1997).

Luhmann's concept of the world society transcends in a crucial aspect 
existing theories of globalisation. It ascribes to the world society emergent properties and demands from sociology to contextualise globalisation. It might be useful to distinguish conceptually between internationalisation, globalisation and world society. Internationalisation can be defined as intensification of relations between nations, respectively states in the form of strengthening of existing as well as the creation of new international organisations and entering new agreements. Globalisation tries to describe the new quality and dynamic that comes with the change in temporal and spatial distances as a result of new communication technologies. The concept of the world society, finally, describes the context in which these globalisation processes occur.

\subsection{LAW AND POLITICS IN THE WORLD SOCIETY}

If the analysis of the world society is orientated consistently at worldwide processes of communication, there should be no doubt that structures of world law and world politics emerge. Luhmann's theory of politics is able to 'grasp the world in its radical contingency' (Christodoulidis 1998, p. 281). Furthermore, what Luhmann emphasises is that each function system shows high degrees of complexity that require not only sophisticated ways of reducing these complexities but that function systems create problems for each other due to the lack of any proper coordination at the global level.

... there is no longer a quasi cosmological guarantee that structural developments within function systems remain compatible with each other. Science does not add knowledge to power but uncertainty and risk to decisions. Physics made it possible to produce the atomic bomb, the economy finds it profitable to use high risk technologies - both with enormous impacts on the political system. The free press changes politics into a turmoil of scandals and enforces and reveals hypocrisy as the typical style of political talk, and this leads to a widespread critique of the 'political class' and to a decline of political trust. The highly efficient modern medicine has demographic consequences. The new centrality of international financial markets, the corresponding marginalization of production, labour and trade, and the transfer of economic security from real assets and first rate debtors to speculation itself, leads to a loss of jobs and seduces politicians to 'promise' jobs (without markets?). The welfare state produces completely new problems for the legal supervision of politics and leads to deformations of legal doctrine that undermine the predictability of legal decisions. On the other hand, the corresponding judicial 'legislation' of constitutional courts affects politics in a way that can hardly be called 'democratic' (the degree of centralization of the emerging European Union will not be decided by the governments in London, Paris or Berlin but by the European Court in Luxembourg) (Luhmann 1997b, p. 76). 
Luhmann outlines here the particular challenges that the legal system faces in the world society. Its performances for other social systems change, in the first place due to the changing role of the political system that is no longer organised by a state at the global level. For Luhmann the role of law and politics as risk-bearers of societal evolution decreases in the world society. However, this does not mean that law is withering away but that we can expect a change of the legal form. Luhmann emphasised early on that the growing importance of the economy, science and technology in the world society is the result of an increase in cognitive expectations in a world society oriented towards the future rather than the past (Luhmann 1975 [1971], pp. 55-8, 1985a, pp. 262-3). I view this early thesis of Luhmann, despite Rudolf Stichweh's objections (Stichweh 2002, p. 287), as still being valid. In the world society the relevance of law and politics (although not necessarily their amount) for the society as a whole decreases. At the same time we can expect an increase in cognitive mechanisms within the normative structure of world law.

In describing the backwardness of law and in particular politics in the world society, Luhmann uses the interesting comparison with the diminishing role of families in the formation of complex societies.

A rapid increase in worldwide coherence is perceptible in all ... areas. The same is true for political power to the extent, that all, at least great, powers can no longer afford to ignore the shifts in power relations amongst the small powers somewhere on the globe. In contrast to this, political decision-making, and hence political rationality within more narrow boundaries, seems to lag behind - just like the family used to in the construction of larger and highly cultivated societal systems (Luhmann 1985a, p. 256).

Like other function systems, the political system is governed by a binary code. Luhmann identified this code as government and opposition. Some critics have accused him of adhering to a model of politics predating the Enlightenment period in which democracy is substituted by administration (King and Thornhill 2003, p. 181). This criticism is not only unfair but misleading, since Luhmann is particularly aware of the problems of politics in a late stage of modernity in which world politics become increasingly dominant. However, questions can be asked at a different level about Luhmann's code; it creates problems in relation to the system of world politics since there is no single government representing the system. Mathias Albert has made the interesting point that in the development of the world political system, for a while at least, the East-West divide during the period of the Cold War acted as functional equivalent to the binary code of government and opposition (Albert 2004b, pp. 27-8; see also Albert 2004a). 
Law and politics are the function systems that have the most difficulties in accepting their links with and dependence on the world society as central to their self-understanding. Territorial boundaries and national and regional identities play a larger role in comparison with other function systems. In addition, law and politics reinforce each other in their insistence on national and regional self-identity.

The specific concept Luhmann adopted in order to theorise links between function systems is structural coupling. Zones of structural coupling are areas in which the systems have the potential to irritate each other. The constitution is Luhmann's main example of structural coupling of the legal and the political system; property and contract are the main mechanism of structural coupling of the economic and the legal system (see Luhmann 2004, ch. 10).

The concept of structural coupling rests on three assumptions. First, the systems involved are conceived as autopoietic in nature and thus, despite any relationship, ultimately guided by their necessity to self-reproduce. Second, structural coupling means a specific, non-causal form of influencing; through mechanisms of structural coupling systems irritate each other by becoming aware of different operations and interpretations of the other system that can become the cause for internal structural adjustments. ${ }^{3}$ Third, over the long run structural coupling is a condition that enables coevolution of the coupled systems.

The last aspect refers to a specific relationship that is assessed with concepts borrowed from the general theory of evolution and contingency theory. Luhmann discards any deterministic theory of society and thus rejects explicitly viewing the relationship of societal and legal, respectively, political development as being causally linked. Law and politics are seen as genuinely autonomous areas and their study requires non-linear thinking. His insistence on difference as the starting point in theorising the social world, his system-relative worldview and the prominence his theory puts on non-causal relationships bears resemblances to postmodern thinking. The closeness of Luhmann's system theory to postmodern thinking about law has been commented upon in the writings of Teubner, Ladeur, Clam and a few others (see Teubner 2001, 2006b; Ladeur 1995; Clam 2000; see also Goodrich 1999). We find indeed a number of affirmative remarks on Derrida's différance concept in Luhmann's late work (for example Luhmann 1993, 1995b), although, one should be fair, these

3 Teubner has suggested using the term 'interference' for the description of simultaneous effects of communication events in several function systems. See Teubner 1993a, pp. 86-90. 
constitute only side remarks and show no real engagement with postmodern theorising.

Luhmann is sceptical whether the concept of structural coupling of law and politics via constitutions can be transposed to the world society. Even before he adopted the concept of structural coupling he argued in the early article on Weltgesellschaft: 'It might be possible that the peculiar relationship of law and politics is an aberrant specialisation that, for the time being, cannot be transferred on to the system of the world society' (Luhmann 1975 [1971], p. 57, translation R.R.). A similarly radically negative attitude is taken at the end of Law as a Social System regarding the future role of law in the world society:

... it may well be that the current prominence of the legal system and the dependence of society itself and of most function systems on a functioning legal code are nothing but a European anomaly, which might well level off with the evolution of the world society (Luhmann 2004, p. 490, translation adjusted by R.R.).

However, despite Luhmann's pessimism there might be new relationships between law and politics developing at the global level. Structural coupling might be replaced by new links between law and politics. An interesting concept is pursued by Poul Kjaer, who suggests that world politics provides new forms of legitimacy for world law (Kjaer 2012). National political structures like the public sphere and representation are replaced in world politics by new structures of communication based on general principles of accountability and transparency (Kjaer 2011). It might well be that a major function of world law in the form of global administrative law is vice versa to provide support for the building of political structures on the basis of these principles (on global administrative law see Kingsbury et al. 2005).

Nevertheless, it is worthwhile remembering that Luhmann was particularly sceptical about the capacity of law to address and regulate the problems that world society creates for itself. He identified these problems as related to tendencies of exclusion and failed inclusion of large parts of the global population into function systems. The emergence of the metacode of exclusion and inclusion in the world society has consequences for the application of the legal code of legal and illegal.

The difference between legal and illegal certainly exists and there are legislative programmes (statutes) that regulate how the values of legal and illegal are attributed to facts. But this question is of little importance to the excluded groups of the population compared with what is imposed on them by this exclusion. They are treated legally or illegally and accordingly conduct themselves legally or illegally (Luhmann 2004, p. 489). 
He then continues in a typical Luhmannian twist that a similar observation can be made about inclusion.

The same applies to those who are included and, in particular, to the politicians and the staff of bureaucracies (Ibid.).

The most severe problems in the world society result from negative functional differentiation. World politics and world law lose their role as main sources for the creation of structures in the world society. Due to high internal complexity, function systems develop along their own trajectories at different speeds and there are no instances in the world society prepared to deal with collisions of function systems. The global financial crisis might well have revealed this dark side of functional differentiation of the world society (Kjaer et al. 2011).

Luhmann's bleak view of future dangers of the world society bears remarkable similarities with Max Weber's pessimism about the development of modern society. Weber's view of an ever more efficient rational bureaucratised society becoming an uninhabitable iron cage for mankind finds an echo in Luhmann's warning of increasing burdens that function systems create for each other. Weber's scepticism towards rationality in general re-emerges at the end in Luhmann's negative appraisal of chances for system rationality in the world society in coping with its self-inflicted problems.

\subsection{NIKLAS LUHMANN'S WORLD LAW AND GUNTHER TEUBNER'S GLOBAL LAW}

The theory of world law tries to understand the emergence of a separate order of norms at the global level. Traditionally world law is identified with international law, which comprises public international law, including fundamental and human rights. Public international law is created through agreements between states and the states are 'primary subjects' of international law. There is an on-going discussion in international law in which way it is capable of becoming autonomous and develops, despite fragmentation, its own structures and dynamisms beyond the control of nation states (Cassese 2005, Part II; Koskenniemi 2007).

In Law as a Social System Luhmann argues that the world society 'has a legal order, even if it does not have central legislation and decision-making' (Luhmann 2004, p. 481). This world law is based on a number of commonalities among the different regional or national legal orders: the universal existence of legal concepts such as property, contract and rules of private 
international law as well as legislation as source of law. However, unlike science or the economy, the legal system in the world society is characterised by enormous differences among regional and national legal orders. These are to a significant degree the result of 'segmentation' of the political system into states at the global level. This 'secondary differentiation' has negative consequences for the establishment of a system of world law.

Human rights constitute a special case. At the international level the cornerstone of human rights legislation has been the Universal Declaration of Human Rights of 1948. This document not only contains a wide range of individual rights, including liberty and security, equality before the law, freedom of expression and religion and prohibitions on torture, but also political, social and economic rights such as asylum, right of assembly, right to work and equal pay, right to social security and right to education.

In assessing the role of human rights within world law it might be helpful to compare them with Luhmann's assessment of world religions. He describes the emergence of world religions in A Systems Theory of Religion (Luhmann 2013) as a prime example of anticipation of the world society. They are the most important contribution to the differentiation of religion as a social system in the world society. What prepares some religions more than others to become world religions is their universal nature and that they offer their religious contents to all human beings. World religions do not operate with ethnic, racial or territorial limitations nor are they supported, like Japanese Shintoism or Judaism, by these factors. Gods are de-regionalised and the only criterion that matters is belief. World religions are radically individualistic and have to find justification in themselves (Luhmann 2013, pp. 199-200).

I suggest viewing human rights as a parallel case to world religions within the legal system. Human rights grant rights to all human beings on the globe. They are individualistic and inclusive and play an important role in the establishment of a world legal system.

Furthermore, Gert Verschraegen has rightly emphasised that Luhmann's theory of human rights grants them a double meaning in modern society: human rights not only protect individuals but also society from de-differentiation (Verschraegen 2002, 2006). Human and fundamental rights play an important role in preventing the political system from resorting to drastic solutions. Fundamental rights are 'institutions' that protect modern society from regression (see Luhmann 1965).

Luhmann notes in the last part of Law as a Social System (Luhmann 2004, pp. 479-90) the difficulties legal theory has in justifying human rights. Natural law and social contract theories are exhausted and all attempts to recognise human rights as positive law in constitutional law are riddled with paradoxes. Why is something supposedly above positive 
law in need to become positive? Furthermore, Luhmann diagnoses undermining tendencies that derive from an inflationary use of human rights as a symbolic medium, a warning resembling Hannah Arendt's "perplexities of the rights of man" (Arendt 1973, pp. 290-304), which, insofar as economic and social rights are concerned, has never been very convincing from a labour law perspective.

Nevertheless, Luhmann acknowledges that human rights play an invaluable part in the emerging law of the world society and are one of 'the most important indicators of a global legal system' (Luhmann 2004, p. 482). In Luhmann's sociolegal analysis the reasons for the human rights discourse to flourish are external. Outcries about severe violations keep the discourse on human rights alive. Thus, neither increasing efforts to legalise human rights through codes and attempts to clarify them in precise legal texts nor the expansion of human rights from protective to supportive rights are the main reasons for the growth of human rights. Instead, external factors such as public demands for reactions to massive incursions of human rights and crass cases of violation of human dignity are the guarantors that human rights continue to be taken seriously (Luhmann 2004, pp. 483-7).

Luhmann's theory of world law is not a normative theory and differs in this respect from current political and legal theory. Unlike John Rawls' The Law of Peoples (Rawls 1999), Luhmann does not offer a normative programme of how to create a 'just' international order on the basis of 'just' institutions. ${ }^{4}$ Luhmann's world society concept also differs from the Kantian programme of establishing a utopian world order that guarantees eternal peace for cosmopolitan citizens. This Kantian project has recently been reformulated by Jürgen Habermas in his 'Political Constitution for the Pluralist World Society' (Habermas 2008; see also Habermas 2006, 2009). Habermas proposes a new form of world organisation that replaces the UN and derives its legitimation partly from a well-informed global public sphere.

The goal of a democratic constitution of world society calls for the creation of a community of world citizens ... a constitution-building cooperation of citizens and states . . . a cosmopolitan community. The latter would not constitute itself as a world republic . . . but as a supranational association of citizens and peoples (Habermas 2012, p. 58, emphasis in text).

Habermas's theorising of world law privileges political and constitutional aspects and largely overlooks other processes that typify modern law. This

4 And Luhmann is certainly not interested, like Rawls, in justifying 'just' wars against so-called illiberal and indecent people. 
narrow view has characterised his understanding of law since he embarked on rethinking the relationship between law and democracy in Between Facts and Norms (Habermas 1996a). Luhmann criticises Habermas's normative approach for too much 'faith in the legal process' and 'a very traditional emphasis on legislation' (Luhmann 1996a, pp. 891, 892). Furthermore, Habermas's concern with legitimation as the most pressing problem of modern law and politics itself lacks legitimation (Luhmann 1996a and reply by Habermas 1996b; see also the debate over the question of legitimation in Habermas and Luhmann 1971).

For Luhmann world law is more than public international law. Although he has not analysed world law in detail, there was no doubt for him that a legal system exists in the world society which has 'a structure of legal norms, independent of regional traditions and the political interests of regional states' (Luhmann 2004, p. 487). However, since this global legal system is not regulated by central legislation and decision-making, public international law and, for example, an international court do not occupy the centre of Luhmann's understanding of world law.

Gunther Teubner has further developed Luhmann's rudimentary thoughts about law in the world society in his studies on global law without the state. The legal system of the world society has no centre from which it can expect to be governed in order to preserve its unity (Teubner 1997). Teubner looks beyond (public) international law, which, in his view, gets too much attention in comparison with the law of conflicts or 'collisions' between legal orders, which is traditionally seen as the sphere of private international law (Fischer-Lescano and Teubner 2004). A theory of global or world law has to focus in Teubner's view on the genuine properties of the legal system that emerges at the world level.

Teubner has convincingly applied the theory of legal pluralism in studying world law (Teubner 1997). In his account, global law is plural in nature and consists of a variety of legal orders that globalise gradually and at different speeds. In theorising global law Teubner makes creative use of Eugen Ehrlich (Ehrlich 2002 [1936]) and his study of customary law in modern society. For Teubner, global law, like customary law, derives from a multiplicity of legal sources and, by viewing global law as similar to customary law he started a third wave of studies in legal pluralism, following the first wave of legal pluralism studies of colonial legal orders and a second wave of successfully applying the theory of legal pluralism in studies of multicultural Western law and its semi-autonomous ethnic, cultural and religious legal orders (Teubner 1997). In creatively using Ehrlich's original ideas, Teubner argues that world law emerges from social peripheries and not from political centres occupied by nation states or international organisations. He emphasises that main sources for the 
emerging world law are international trade agreements and their interpretation through international commercial arbitration and other quasijudicial bodies.

Three examples of genuine world law can illustrate Teubner's claim of a global law beyond the state. Probably the best example is lex mercatoria. This legal practice, which dates back to medieval times, has developed into an established, separate legal order of international trade law. According to Ursula Stein, indicators for the existence of a separate legal order are high standards of transparency, observance of principles of international law, use of precedents for establishing principles used in decision-making and an efficient practice of commercial arbitration that is able to enforce its decisions (see Stein 1995, pp. 241-3 and ch. 7 III on lex mercatoria as a legal order). The legal order of lex mercatoria has emerged as a subsystem within the world legal system through self-referential, reflexive operations. It is an indication that law is undergoing a structural transformation in the world society. Its traditionally close relations with politics are loosening and are exchanged in the case of lex mercatoria with closer links with transnational economics (Albert 2002, pp. 262-3; Lieckweg 2003).

A further example of the emergence of a specific type of world law independent of international, respectively, interstate law is the area of professional sports. The globalisation of sports has led to an increase in activities of athletes, clubs, federations, sponsors or event organisers at regional or global levels. These sport-related, including economic, activities are governed by specific rules that require specialist knowledge from judicial bodies dealing with disputes arising from these activities. Like lex mercatoria, international sports law has developed into a highly complex legal order adhering to high standards. Ken Foster has made an interesting distinction between international and global sports law:

International sports law (consists of) general principles of law that are automatically applicable to sport. Basic protections, such as due process and the right to a fair hearing, are by this route incorporated into sport and represent a 'rule of law' in sport. Global sports law ... describes the principles that emerge from the rules and regulations of international sporting federations as a private contractual order. They are distinctive and unique (Foster 2003, p. 4).

Crucial for the development of global sports law has been the Court of Arbitration for Sport (CAS), which, since the early 1980s, resolves sports disputes of the international sporting community. CAS is a separate judiciary that has its seat in Switzerland. It is an independent institution under the administrative and financial authority of the International Council of Arbitration for Sport that provides the settlement of sports-related disputes through arbitration or mediation by means of procedural rules 
adapted to the specific needs of the sports world. CAS has had a decisive function in establishing internationally recognised principles on which sports law developed into a separate global legal order.

A third example is lex digitalis, or the law of the Internet. Gralf-Peter Calliess has called this legal order genuine transnational law, which he defines as follows: 'a third-level autonomous legal system beyond municipal and public international law, created and developed by the law-making forces of an emerging global civil society, founded on general principles of law as well as societal usages, administered by private dispute resolution service providers, and codified (if at all) by private norm formulating agencies' (Calliess 2002, p. 188). His example is the system of dispute resolution of the Internet Corporation for Assigned Names and Numbers (ICANN), which has been in operation since 1999 and shows all the attributes mentioned in his definition. Calliess emphasises that the transparency and the fact of full publication of all ICANN decisions have been decisive for the emergence of a separate legal order resulting from self-referential decision-making, a case based on precedent. Teubner goes a step further and sees in this decision-making signs of an emergent digital constitution (Teubner 2004a). ${ }^{5}$

The new quality of global law lies for Teubner in mirroring functional differentiation of the world society and so-called polycentric globalisation in the sources of law. To a large extent world law originates in self-regulation processes in function systems. These processes lead to complex legal orders within function systems that develop their own strategies of reduction of complexities. This gives world law the character of polycentric law (Teubner 2012).

In recent studies of these global legal orders, Teubner has gone a step further. What is most characteristic for him about legal globalisation is the emergence of societal constitutions in these legal orders (Teubner 2002, 2004a, 2004b, 2010a, 2010b, 2011a, 2011b, 2011c). Societal constitutionalisation accompanies constitutionalisation in the public sphere, in international politics and in international organisations, epitomised in the development of human rights applied worldwide (on constitutionalisation beyond the state in public international law see Pernice et al. 2012). For Teubner this constitutionalisation of international politics represents only a:

5 Six further examples of emerging legal orders in the world society are discussed in Fischer-Lescano and Teubner (2004). These include transnational copyright law, medical patent protection, transnational construction law (lex constructionis), transnational criminal law (law of the disappeared), international financial regulations (lex financiaria) and transnational cybercrime law. 
sub-constitution of world society among others, which can no longer use any pars pro toto claim. ... The ongoing constitutionalisation of international politics has no monopoly over constitutionalising world society. A kind of constitutional competition is set into motion by the autonomisation of global sub-constitutions (Teubner 2004b, p. 15).

Teubner is not alone. We witness an increasing interest in global legal structures that have led to a multitude of normative and empirical studies. In philosophical perspectives global legal structures are assessed as normative orders, predominantly focusing on questions of distributive justice (Rawls 1972; Pogge 1989, 2007a, 2007b). Newer philosophical accounts transcend the narrow justice discourse and focus on broader legitimacy questions. In this view the problem of the global order is not justice but justification and world law is assessed whether it guarantees a so-called right to justification (Forst 2011). The analytical interest shifts to studying the emergence of the global normative order from a particular normative perspective that asks whether global law is a site for the creation of concrete moral and legal norms guaranteeing the possibility and chances for resistance of this order (Forst and Günther 2011).

However, such views on world law are limited. More promising is sociological theory and in particular legal sociology. World society theorists argue that international law is only possible because of the existence of a normative structure of expectations at the world level (Stichweh 2000a, p. 55). These expectations develop in different function systems and lead not only to separate systems of norms but to a whole range of institutions dealing with upholding expectations. An overarching unifying view based on moral principles is no longer providing integration of world law or steering these institutions. Questions of legitimacy no longer play a central role and the global legal orders engage at best in 'reflexive legitimacy' through procedural rationalisation and professionalisation of self-regulation (Banakar 1998; Dezalay and Garth 1998).

Sociolegal research has begun to analyse the diverse global legal processes and institutions and the orders in which they are embedded. Law plays a specific role in multi-level governance of global trade (Picciotto 2011) and in areas such as global environmental law (Perez 2004). In transnational commercial disputes, in particular in the case of cross-border debt, a privatisation of debt collection and the emergence of a private law order have been observed (Budak 1998). And there is the fascinating case of globalisation of law firms and legal practice (see Dezalay and Garth 2012; Günther 2004; Flood 2008).

Studies report a number of ways in which global legal orders strengthen themselves through self-regulation. Empirical studies of self-governance in transnational economic transactions emphasise the public function of 
so-called private forms of self-regulation (Glinski 2008 and other studies in Dilling et al. 2008; see also Teubner 1994, 2010a). Volkmar Gessner (1998) identified legal rules, professions, so-called third cultures (scientific communities, the mafia, the London reinsurance market or the diamond industry) and state and non-governmental support structures as factors that produce 'legal certainty' in global law.

\subsection{FROM THE IDEA OF LABOUR LAW TO A THEORY OF LABOUR LAW IN THE WORLD SOCIETY}

What do these theoretical and empirical findings about an emerging world law mean for labour law and how can we assess its role in the world society? This has to be a central question for a theory of reflexive labour law. There is currently much uncertainty about the future of labour law. Guy Davidov, Brian Langille and their colleagues evaluate the status of labour law by re-assessing the normative and intellectual foundations of what they call the Idea of Labour Law (Davidov and Langille 2011). However, such internal reconstruction of the logic of labour law development and its challenges provides limited answers. For a proper understanding of modern labour law it is necessary to move beyond retrospective analyses or using memory as means of regaining a lost world of pluralist labour regulations (Arthurs 1998). What is needed is an assessment of labour law's changing role in the world society.

For this an analysis is required that looks at internal transformations of labour law as well as its co-evolution with the economic and political system but also industrial relations. These systems have themselves encountered transformations in large part due to globalisation. Industrial relations operate as a separate social system in the world society (see Chapter 3). The creation of labour law as a separate field of regulation and discipline is originally a response to the emerging industrial relations system within the legal system. The relationship of labour law as a subfield of the legal system to the industrial relations system is of central concern for a system theoretical account of labour law.

Furthermore, labour law is linked to politics, in particular in the context of economic policy-making. It is regularly exposed to attempts of the political system that try to regulate labour law in the hope of achieving economic goals. For an understanding of the development of modern labour law we have to look at different levels of governance. As far as the global level is concerned, I would like to suggest that global labour law, at least in the form of international labour law, is located in a specific zone 
of structural coupling between world law and world politics. Mathias Albert emphasises in his studies on world politics a specific mechanism of structural coupling of law and politics in the world society which he calls international regimes (Albert 2002, pp. 291-8, 2004a). These regimes transcend international organisations, which themselves become dependent on processes resulting from transnational regimes. In using this analysis, global labour law can be understood as having evolved into a legal regime in the world society (further discussed in Chapter 10).

However, globalisation of labour law does not only happen at the global level. Tania Lieckweg (2003, pp. 133-4) has rightly emphasised that globalisation of law differs among areas of law, in particular in relation to relevance of sources of law other than legislation. Labour law has a long tradition of dealing with norms created in non-statist settings and might indeed be a case of spontaneous creation of law in peripheries. Important sources of norm creation in labour law are collective bargaining and company negotiations resulting in collective bargaining agreements and company agreements. These are acknowledged as sources of law and play an important role in shaping economic processes. From a reflexive law perspective they constitute mechanisms of self-regulation that pose challenges for public labour law regulations (a topic that will be further discussed in Chapter 2).

What should be clear from these remarks is that labour law operates in a particular context and this is created by the social system of industrial relations. Industrial relations are also undergoing transformations due to globalisation in the world society. A few remarks should suffice to illustrate these globalisation processes, which will be further discussed in subsequent chapters.

In the global age strikes of a certain size are reported worldwide as important economic news. Wage struggles and negotiations over working conditions are perceived as events which have an impact beyond national markets. The costs of transnational companies with production sites in several countries are directly affected by strikes in a particular country. Thus, collective bargaining and strike threats in German industries are important beyond Germany. Furthermore, strikes of lorry drivers in one European country have a direct impact on economic activities in other European countries and beyond.

It is alleged that the demand for decent labour standards reduces the chances of developing countries to compete with low labour costs. A national strike in developing countries receives almost immediate worldwide attention because labour unrest is automatically viewed as reaction to global pressures of introducing policies of liberalisation and flexibilisation in these countries. Although the strike reasons often are local 
or national in origin, for example a change of national dismissal law or discrimination of trade unions, the protest receives global news coverage because it is perceived as a direct response to social injustices resulting from free market policies.

The reform of legal policies and labour law are increasingly driven by global concerns. Deregulation of employment protection is commonly justified by expectations of an alleged international demand for flexibilisation of workforces. These experiments with massive deregulation of labour law receive much attention, for example the radical abolishing of employment protection in New Zealand in the 1980s and 1990s, and are openly used as means in competition over foreign investments.

If we look at supranational or international law and policy-making, a number of processes can be discerned. In the European Union the socalled social dimension officially accompanies economic integration. It consists of social and labour policies that have led to a number of 'hard' legal rules in areas such as health and safety of workers and equal pay and equal treatment between men and women. These laws are vigorously enforced by European institutions with active support from the European Court of Justice. In addition to the core of hard rules, there exists a variety of 'weak' supranational legal norms in the European Union, many of which have been introduced since 1997 in the context of coordination policies as part of the European Employment Strategy.

European social policy measures are not the outcome of corporatist arrangements, as is characteristic of many national labour law systems. They form part of neo-voluntarist policies following a programme of neoliberal restructuring of national economies (Streeck 1996). Nevertheless, European social policy and labour law provide a basic frame for transnational private regulation in Europe (Bercusson 1997). This includes promotion of sectoral collective bargaining and European works councils in the European Union (Bercusson 2009a, ch. 9).

In switching from the European to the international level, we notice attempts to add a 'social dimension' to globalisation by establishing a global legal framework of labour standards. International labour law derives foremost from labour standards introduced by the International Labour Organization (ILO). For the development of international labour law the ILO is still the leading source. It has transformed from a pure standard-setting agency for the harmonisation of national labour law to a true international organisation that pursues its own policy agenda. In particular its Decent Work agenda enables the ILO to create global labour law that reaches beyond the confines of national labour law into labour market policies and regulation of multinational corporations. The switch was supported when the World Commission on the 
Social Dimension of Globalisation elevated decent work as its key concept for future employment policies. This provided 'political direction' and boosted policy efforts pursued by the ILO (Casale 2011, p. 2).

However, global labour law transcends international labour law. Labour law norms are increasingly created in private settings and result from activities of networks in which ILO standards form part of norm creation. In their project on transnational private law, Gralf-Peter Calliess and Peer Zumbansen (2010) emphasise the importance of networks for the creation of world law. Furthermore, although networks no longer privilege the nation state as source of law, nation states play a role in them in creating transnational law. They rightly point out that major changes have occurred at the domestic level which are related to the use of new forms of governance and soft law. Applied to labour law we can speak of global labour law as a regime emerging from links between the function systems of law, politics, economy and industrial relations at global, regional and domestic level.

A small example of globalisation of labour law resulting from network activities is international cooperation and mutual observation of labour courts and other judicial bodies dealing with labour law matters. These processes are sources for the creation of labour standards in the judicial realm. Although it would go too far to talk of a 'global community' or network of labour courts (on the idea of a global community of courts see Slaughter 2003, 2004, ch. 2), there are signs that labour courts take notice of foreign decisions in their judicial practice and form more or less informal organisational links. For example, labour court judges operating in the European Union and the European Economic Area have formed their own Association of Labour Court Judges, which holds an annual conference and occasionally produces reports on topics of mutual concern and relevance for European discussions.

Global labour law is closely linked to developments of international business and trade law (see Hepple 2005). The legal framework of international trade law develops in incremental processes and is supplied from a variety of sources (Braithwaite and Drahos 2001; Picciotto 2011). There is much less reliance on statutory law or collective agreements. International trade agreements might contain social clauses and other labour law provisions. Furthermore, internal structures of transnational corporations might reflect national company constitutions in which employee representatives enjoy co-determination rights and thus become part of global labour law.

An important means for the development of the so-called social dimension of globalisation are codes of conduct of companies operating at the 
global, regional as well as domestic level. They regulate, for example, that suppliers of multinational corporations have to observe labour standards. These codes of conduct often refer to ILO conventions. However, they are also sources for the creation of transnational regulation (Backer 2008). Since sanctions for non-compliance, respectively their lack, can generate problems, codes of conduct create opportunities for collective actors, including trade unions and social movements, to engage in campaigns that demand adherence to labour standards.

Fundamental economic and social rights are a further area of law that contributes to the formation of a global labour law regime. The rights include the right to work, which is defined in Article 23.1 of the Universal Declaration of Human Rights in the following way:

Everyone has the right to work, to free choice of employment, to just and favourable conditions of work and to protection against unemployment.

However, this right has the problem that in order to be effective it has to be viewed as more than just an individual right. In Article 6 of the International Covenant on Economic, Social and Cultural Rights, the right to work is linked to responsibilities of states for vocational training and other measures supporting individual development.

(1) ... the right to work ... includes the right of everyone to the opportunity to gain his living by work which he freely chooses or accepts, and will take appropriate steps to safeguard this right. (2) The steps to be taken by a State party to the present Covenant to achieve the full realization of this right shall include technical and vocational guidance and training programmes, policies and techniques to achieve steady economic, social and cultural development and full and productive employment under conditions safeguarding fundamental political and economic freedoms to the individual.

The right to work as understood by the International Covenant on Economic, Social and Cultural Rights is intricately linked to employment policies. Modern labour law can indeed not be separated from labour market policies. We witness a worldwide trend of refocusing the regulatory concern of employment policies from employment rights to employment promotion.

An important factor in developing the social dimension of globalisation has been the interaction of regional and global efforts in regulating employment and industrial relations affairs. In particular, the experience of the supranational European social and employment policy and its relationship with collective interest groups has been an important source of innovative labour law making. In the EU collective, industrial actors 
participate not only in implementing EU law but have an active role in creating European labour law in the context of the so-called Social Dialogue.

However, the so-called social dimension of European integration underwent two transformations. The first transformation occurred in the 1970s when the initial minimalist policy of simply supporting economic integration and the establishment of a common market with a few social policy measures were abandoned and European social policy became a separate policy field in its own right. In fact, with the active support of the European Court of Justice, social integration was declared to be of equal importance to economic integration as a goal of European policy-making. The second transformation occurred in the 1990s with the adoption of employment policy as an official area of policy-making in the European Union. The focus in relation to labour law shifted from employment protection to employment promotion. Increasing employment rates became an overarching goal since 2000 and included initiatives of modernising labour law in accordance with demands for flexible labour markets (see the Green Paper Modernising Labour Law to Meet the Challenges of the Twenty-First Century, European Commission 2006a).

Efforts to establish an internal social dimension of European integration were accompanied in the EU by initiatives for an external social dimension. Particularly noteworthy is the inclusion of labour standards in the so-called Generalised System of Preferences (GSP). Since 1 January 1998 a social clause is part of trade agreements of the EU with developing countries. It operates with incentives of trade advantages if labour standards are adhered to but developing countries lose their trade preferences in case of violation of labour standards (further discussed in Chapter 10).

The relationship of labour law and industrial relations is changing in the world society. The new communication technologies encourage new forms of solidarity. They offer social movements, including the labour movement chances of influencing world politics and gaining attention for their causes. Worldwide communication systems enable a rapid distribution of information about local or regional industrial disputes. Industrial disputes over wage bargaining and trade union rights as well as specific labour law problems such as dismissal or statutory minimum wages gain almost immediate international recognition. Furthermore, global communication has increasing importance for initiating and conducting collective industrial disputes. In fact, globalisation has the potential to strengthen industrial relations in this way.

No doubt there are also negative impacts of globalisation on industrial relations. What has been commented on in relation to smaller nation states in world politics is even truer for national industrial relations: they lack an 'address' for international communications. Their voice is often 
not heard in regulation of social affairs and labour law at the international or supranational level. This can lead to phenomena such as social dumping, when the lowest standards become the point of convergence in regulating social security and lead to a reduction of protection in developed labour law systems. There is also the famous 'pressure from outside' to deregulate national labour law. However, it would be wrong to assume a standard model or pattern of deregulation. The autopoietic nature of industrial relations is often able to resist deregulation pressures (see Chapters 3 and 6).

If globalisation is mainly associated with markets and free trade, the adoption of labour law and collective bargaining at supranational and international level indicates the limits of globalisation. Liberalisation of the world market will not be able to retain growth over a longer period if it is not properly regulated. The world market, like all other markets, requires a re-forming of capitalism in order to achieve growth with stability (Streeck 2009; Boyer and Drache 1996).

Insofar as industrial relations and collective bargaining at international level are concerned, much will depend on the role of collective organisations and their role within the new contexts of corporate codes of conduct and corporate social responsibility. Transnational solidarity indeed faces severe problems for trade unions (Bieler and Lindberg 2010). Since support from an active welfare state and the legal system is largely lacking, traditional trade union internationalism will have to find new partners at the global level. Social movements promoting human rights, in particular those of migrants, are possible candidates. In utopian versions of a law of humankind, which creates the basis of a global community, replacing both the state and the market as regulatory sites, labour might find support and a place in transnational coalitions (Sousa Santos 2002, pp. 365-73). And unions might find a new role in supporting alternative values in civil society (Crouch 2011, ch. 7), but this requires trade unions, as Richard Hyman aptly observes, to diversify their forms of solidarity (Hyman 2010).

However, it is more likely that the globalisation of the labour movement takes place at home. Indeed, increased recognition of the local through global exposure already supports labour movements in their endeavours. Achievements at the workplace and in collective negotiations can rapidly be disseminated in the global world. Furthermore, the global challenge to workplace industrial relations releases new energies to defend and even strengthen existing institutional regimes (Bélanger et al. 1994). Autopoietic industrial relations and reflexive labour law of advanced national economies become mediating forces which protect their achievements through endorsement of their global role. Insofar as collective 
bargaining at sectoral and company level and national labour law systems are able to accept the global challenge through reflecting their global position, these confident local, regional and national industrial relations will constitute important premises of the world society.

Let us summarise. The theory of reflexive labour law takes seriously the globalisation of labour law. Labour law develops at different levels, which all are influenced by worldwide processes of increasing fragmentation and conflicts between regulatory regimes. These processes pose new challenges to regulation and self-regulation of labour law. Furthermore, labour law plays a part in what Teubner calls societal constitutionalisation as a response to functional differentiation in the world society. This phenomenon of globalisation of labour law will be further discussed in Chapter 10.

Luhmann predicts less dependence of the major function systems on both legal regulation and the availability of the legal code in the evolving world society (Luhmann 2004, pp. 479-90). However, labour law and industrial relations will continue to play an important role in shaping conditions under which businesses engage in activities in the global market. They are relevant forces in creating 'cultures' and 'institutional regimes' which have been considered the dominant factors for economic growth, replacing government policies in the global age (Albrow 1996). 